\title{
PENGARUH SENAM YOGA TERHADAP DEPRESI PADA LANSIA DI UPT PELAYANAN SOSIAL LANJUT USIA PASURUAN, LAMONGAN
}

\author{
Ninik Murtiyani $^{1}$, Yufi Aris Lestari ${ }^{1}$, Hartin Suidah ${ }^{1}$, Hendra Ruzzy Okhfarisi ${ }^{1}$ \\ ${ }^{1}$ STIKES Dian Husada Mojokerto \\ *Correspondence: \\ Ninik Murtiyani \\ Email: ninik.akbar@yahoo.co.id
}

\begin{abstract}
Background: Depresi merupakan masalah serius yang perlu segera ditangani sehingga tidak dapat menimbulkan dampak yang merugikan pada lansia. Lansia yang mengalami depresi tidaklah sedikit, sehingga depresi dapat menggangu masalah kesehatan dan kesejahteraan lansia.

Purpose: Tujuan dari penelitian ini adalah untuk mengidentifikasi dan menganalisis senam yoga terhadap depresi pada lansia di UPT Pelayanan Sosial Lanjut Usia Pasuruan di Lamongan.

Method: Penelitian ini adalah quasy-experimental dengan desain penelitian adalah Pre-Post Test with Control Design. Populasi dalam penelitian ini adalah sebanyak 28 lansia dengan dibagi 2 kelompok yaitu 14 lansia sebagai kelompok perlakuan dan 14 lansia lainnya sebagai kelompok kontol. Alat ukur yang digunakan adalah lembar kuesioner GDS. Data analisis yang digunakan adalah uji t test 2 sampel berpasangan.

Results: Hasil penelitian pengaruh senam yoga terhadap depresi pada lansia didapatkan data nilai untuk kelompok perlakuan dan kelompok kontrol diketahui bahwa nilai $p$ value $=0,000 \leq \alpha=0,05$, maka H1 Diterima dan Ho ditolak yang berati ada pengaruh senam yoga terhadap depresi pada lansia di UPT Pelayanan Lanjut Usia Pasuruan di Lamongan.

Conclusion: Dengan melakukan senam yoga terhadap lansia diharapkan terdapat suatu penurunan depresi. Karena dengan melakukan senam yoga secara rutin dapat memberikan suatu ketenangan hati, dapat mengendalikan emosi, serta dapat menjaga keseimbangan kejiwaan lansia didalam dirinya. Juga masih banyak lagi kegunaan senam yoga dalam kesehatan tertama dalam menghadapi stres maupun depresi.
\end{abstract}

Key words: Senam yoga, depresi, lansia

\section{PENDAHULUAN}

Pada masa lanjut usia secara bertahap seseorang mengalami berbagai kemunduran, baik fisik, mental, dan sosial (Azizah, 2011). Banyak faktor yang menyebabkan gangguanmental. Gangguan mental yang sering ditemukan pada usia lanjut adalah depresi (Departemen Kesehatan, 2008). Depresi pada lanjut usia sering tampak sebagai gejala somatik.
Kondisi depresi cenderung meningkatkan produksi adrenalin dan kortisol yang diketahui dapat menurunkan tingkat kekebalan tubuh sehingga seseorang dengan depresi beresiko mudah terserang penyakit. Gangguan depresi pada lansia kurang dipahami sehingga banyak kasus depresi pada lansia yang tidak dikenali dan tidak diobati. Berdasarkan penelitian yang telah dilakukan di UPT Pelayanan Sosial 
Lanjut Usia Pasuruan di Lamongan dengan metode wawancara didapatkan data sekitar $54,54 \%$ lansia yang mengalami depresi dipanti tersebut. Dampak gangguan depresi yang lain pada lansia berasal dari faktor fisik, psikologis dan sosial yang saling berinteraksi secara merugikan dan memperburuk kualitas hidup dan produktifitas kerja pada lansia. Faktor fisik yang dimaksud adalah penyakit fisik yang diderita lansia. Faktor psikologis meliputi kondisi sosial ekonomi dan kepribadian premorbid, sedangkan faktor sosial yang berpengaruh adalah berkurangnya interaksi sosial atau dukungan sosial dan kesepian yang dialami lansia (Kaplan, 1998). Depresi merupakan masalah serius yang perlu segera di tangani sehingga tidak akan menimbulkan dampak yang merugikan. Salah satu alternative penanganan pada lansia yang menderita depresi adalah senam yoga. Dengan menggunakan senam yoga akan dapat membangkitkan pikiran yang lebih positif, karena didalam yoga terdapat banyak sekali pose/ gerakan yang dapat melepaskan ketegangan di syaraf, merenggangkan otot, mengistirahatkan tubuh dan menenangkan pikiran. Didalam senam yoga terdapat teknik meditasi yang membuat pikiran yang tenang, damai, dan rileks dapat mempengaruhi akibat yang ditimbulkan karena adanya pikiran yang negatif. Latihan meditasi yoga dapat menenangkan pikiran dan menimbulkan kejernihan batin, kedamaian pikiran, pemahaman, serta meredakan emosi (Krishna, 2000). Tujuan dari penelitian ini adalah untuk mengidentifikasi dan menganalisis senam yoga terhadap depresi pada lansia di UPT Pelayanan Sosial Lanjut Usia Pasuruan di Lamongan.

\section{METODE DAN BAHAN}

Desain penelitian yang digunakan adalah Quasy-experimental dengan bentuk rancangannya adalah Pre-Post Test with Contol Group Design yaitu peneliti membagi menjadi dua kelompok pada lansia di UPT Pelayanan Sosial Lanjut Usia yaitu kelompok kontrol dan kelompok perlakuan. Kemudian peneliti membandingkan kedua kelompok tersebut.

Populasi dalam penelitian ini berjumlah 30 lansia. Sampel yang digunakan pada penelitian ini adalah lansia yang mengalami depresi di UPT Pelayanan Lanjut Usia Pasuruan di Lamongan berdasarkan rumus didapatkan 28 lansia. Teknik sampling dalam penelitian ini menggunakan Simple Random Sampling. Pada penelitian menggunakan uji statistik $t$ test 2 sampel berpasangan. Jika, $\mathrm{p} \leq \propto<=$ 0,05 maka Ho ditolak, H1 diterima artinya ada pengaruh senam yoga terhadap depresi pada lansia di UPT Pelayanan Lanjut Usia Pasuruan di Lamongan.

\section{HASIL PENELITIAN}

Depresi Sebelum Dilakukan Senam Yoga Pada Lansia Yang Mengalami Depresi Pada Kelompok Perlakuan Dan Kontrol Di UPT Pelayanan Sosial Lanjut Usia Pasuruan Di Lamongan.

Tabel 1. Distribusi Frekuensi Depresi Sebelum Dilakukan Senam Yoga Pada Kelompok Perlakuan dan Kelompok Kontrol Di UPT Pelayanan Lanjut Usia Pasuruan Di Lamongan, April 2016.

\begin{tabular}{|c|c|c|}
\hline \multirow{2}{*}{ Pre - Test } & \multicolumn{2}{|c|}{ Kelompok Penelitian } \\
\cline { 2 - 3 } & $\begin{array}{c}\text { Kelompok } \\
\text { Perlakuan }\end{array}$ & $\begin{array}{c}\text { Kelompok } \\
\text { Kontrol }\end{array}$ \\
\hline Mean & 19.35 & 15.14 \\
\hline Std.Devisiasi & 1.598 & 1.657 \\
\hline Minimum & 16.00 & 12.00 \\
\hline Maximum & 22.00 & 17.00 \\
\hline $\mathrm{N}$ & 14 & 14 \\
\hline
\end{tabular}


Dari tabel 1 dapat diketahui bahwa dari 14 responden pada kelompok perlakuan sebelum dilakukan senam yoga didapatkan rerata sebesar 19.35 dan standart deviasi sebesar 1.598, sedangkan pada kelompok kontrol data sebelum dilakukan senam yoga didapatkan rerata 15.14 dan standart deviasi sebesar1.657.

\section{Depresi Sesudah Dilakukan Senam Yoga} Pada Kelompok Perlakuan dan Kelompok Kontrol Di UPT Pelayanan Sosial Lanjut Usia Pasuruan di Lamongan.

Tabel 2. Distribusi Frekuensi Depresi Sesudah Dilakukan Senam Yoga Pada Kelompok Perlakuan dan Kelompok Kontrol Di UPT Pelayanan Lanjut Usia Pasuruan Di Lamongan, April 2016.

\begin{tabular}{|c|c|c|}
\hline \multirow{2}{*}{ Post - Test } & \multicolumn{2}{|c|}{ Kelompok Penelitian } \\
\cline { 2 - 3 } & $\begin{array}{c}\text { Kelompok } \\
\text { Perlakuan }\end{array}$ & $\begin{array}{c}\text { Kelompok } \\
\text { Kontrol }\end{array}$ \\
\hline Mean & 16.00 & 15.14 \\
\hline Std.devisiasi & 1.568 & 1.610 \\
\hline Minimum & 14.00 & 12.00 \\
\hline Maximum & 19.00 & 17.00 \\
\hline $\mathrm{N}$ & 14 & 14 \\
\hline
\end{tabular}

Dari tabel 2 Dapat diketahui bahwa dari 14 responden pada kelompok perlakuan sesudah dilakukan senam yoga didapatkan rerata sebesar 16.00 dan standart deviasi sebesar 1.568. Sedangkan pada kelompok kontrol data tidak dilakukan senam yoga didapatkan rerata 15.14 dan standart deviasi sebesar 1.610.

\section{Pengaruh Senam Yoga Terhadap Depresi Pada Lansia Sesudah Diberikan Senam Yoga Di UPT Pelayanan Lanjut Usia Pasuruan Di Lamongan.}

Tabel 3. Pengaruh Senam Yoga Terhadap Depresi Pada Lansia Antara Kelompok Perlakuan Dan Kelompok Kontrol Di UPT Pelayanan Sosial Lanjut Usia Pasuruan Di Lamongan, April 2016.

\begin{tabular}{|c|c|c|}
\hline \multirow{2}{*}{} & $\begin{array}{c}\text { Kelompok } \\
\text { Perlakuan }\end{array}$ & $\begin{array}{c}\text { Kelompok } \\
\text { Kontrol }\end{array}$ \\
\cline { 2 - 3 } & $\begin{array}{c}\text { Perubahan } \\
\text { Depresi Post }- \\
\text { Test }\end{array}$ & $\begin{array}{c}\text { Perubahan } \\
\text { Depresi Post }- \\
\text { Test }\end{array}$ \\
\hline Mean & $-3,35$ & 0,00 \\
\hline Std.Deviasi & 1,568 & 1,610 \\
\hline Nilai Minimum & -2 & 0 \\
\hline Nilai Maximum & -3 & 0 \\
\hline $\mathrm{N}$ & 14 & 14 \\
\hline
\end{tabular}

Hasil penelitian menunjukkan bahwa terdapat perubahan depresi setelah diberikan perlakuan pada kelompok perlakuan atau pun tidak diberikan perlakuan pada kelompok kontrol. Khusus pada kelompok perlakuan perubahan nilai rerata sebelum dan sesudah perlakuan yaitu mengalami penurunan sebesar 3,35 poin, sedangkan pada kelompok kontrol mengalami nilai tetap dengan 0,00 poin. Hasil tersebut didapatkan dari pengurangan nilai rerata setelah perlakuan dikurangi nilai rerata sebelum perlakuan. Berdasarkan hasil tersebut didapatkan perbedaan nilai rerata pada kelompok perlakuan mengalami penurunan dan pada kelompok kontrol mengalami nilai tetap. 
Tabel 4. Hasil Uji Statistik $t$ Test 2 Sampel Berpasangan Dengan Menggunakan SPSS For Windows 16.

\begin{tabular}{|c|c|c|c|c|c|c|c|c|c|}
\hline \multicolumn{10}{|c|}{ Paired Samples Test } \\
\hline & & \multicolumn{5}{|c|}{ Paired Differences } & $\mathrm{t}$ & df & $\begin{array}{l}\text { Sig. (2- } \\
\text { t }\end{array}$ \\
\hline & & \multirow[t]{2}{*}{ Mean } & \multirow[t]{2}{*}{$\begin{array}{c}\text { Std. } \\
\text { Deviation }\end{array}$} & \multirow{2}{*}{$\begin{array}{l}\text { Std. } \\
\text { Error } \\
\text { Mean }\end{array}$} & \multicolumn{2}{|c|}{$\begin{array}{l}\text { 95\% Confidence } \\
\text { Interval of the } \\
\text { Difference }\end{array}$} & & & \\
\hline & & & & & Lower & Upper & & & \\
\hline Pair 1 & $\begin{array}{c}\text { Pre } \\
- \\
\text { Post }\end{array}$ & 1.6786 & 2.10913 & .39859 & .86074 & 2.49641 & 4.21 & 27 & .000 \\
\hline
\end{tabular}

Berdasarkan uji statistik yang dilakukan dengan menggunakan uji $t$ test 2 sampel berpasangan dengan menggunakan SPSS for windows 16.0 didapatkan nilai $P$ value (Sig. 2-tailed) adalah 0.000, karena nilai Sig. $\leq 0,05$ maka dapat diambil kesimpulan bahwa $\mathrm{H} 0$ ditolak dan $\mathrm{H} 1$ diterima, yang artinya ada pengaruh senam yoga terhadap depresi pada lansia di UPT Pelayanan Sosial Lanjut Usia Pasuruan di Lamongan pada kelompok perlakuan prepost test.

\section{PEMBAHASAN}

\section{Mengidentifikasi Depresi Lansia}

Sebelum Dilakukan Senam Yoga Pada Kelompok Perlakuan Dan Kelompok Kontrol Di UPT Pelayanan Sosial Lanjut Usia Pasuruan Di Lamongan.

Dari hasil penlitian menunjukkan bahwa dari 14 responden pada kelompok perlakuan sebelum dilakukan senam yoga didapatkan rerata sebesar 19.35 dan standart deviasi sebesar 1.598 Sedangkan pada kelompok kontrol data sebelum dilakukan senam yoga didapatkan rerata 15.142 dan standart deviasi sebesar1.657.

Menurut Noorkasiani (2009), gejala yang bisa ditunjukkan pada lansia yang mengalami depresi antara lain adalah afek depresif, hilang minat, penurunan berat badan, insomnia atau hiperinsomnia, aktivitas psikomotor menurun, kelelahan atau lemas, merasa tidak berguna lagi, rasa bersalah, sulit berkonsentrasi, dan keinginan untuk mati. Sedangkan menurut Azizah (2011), mereka berpikir tidak adekuat, tidak mampu, merasa dirinya tidak berarti, merasa rendah diri, dan merasa bersalah terhadap kegagalan yang dialami, memiliki motivasi yang kurang dalam menjalani hidupnya selalu meminta bantuan dan melihat semuanya gagal dan sia-sia sehingga merasa tidak ada gunanya berusaha. Lansia yang mengalami depresi tertekan, murung, sedih, putus asa, kehilangan semangat dan muram, sering merasa terisolasi, ditolak dan tidak dicintai. Menurut Endah, dkk (2003) dalam Azizah (2011), depresi dipengaruhi oleh beberapa faktor diantaranya adalah faktor psikologis dan faktor psikososial. Faktor psikologis yang berpengaruh pada lansia yang lama tinggal di panti adalah lamanya lansia tinggal di panti. Menurut Maramis (1995), pada lanjut usia permasalahan yang paling menarik adalah kurangnya kemampuan dalam beradaptasi secara psikologis terhadap perubahan yang terjadi pada dirinya. Penurunan kemampuan beradaptasi terhadap perubahan dan stres lingkungan sering menyebabkan depresi. Saat ini banyak keluarga yang menitipkan lansia ke panti werdha karena banyaknya kesibukan pada keluarga tersebut

Berdasarkan hasil yang didapatkan dari penelitian bahwa lansia yang mengalami depresi menunjukkan gejalagejala yang sesuai dengan teori. Gejalagejala tersebut antara lain sesuai dengan parameter GDS yang digunakan dalam penelitian seperti gangguan minat aktivitasnya yang dijelaskan pada teori bahwa gejala dari depresi adalah hilang minat, dan aktivitas psikomotor yang menurun. Gejala lain yang ditunjukkan dari hasil penelitian adalah adanya perasaan 
sedih yang sesuai dalam teori yaitu murung, sedih hingga bisa timbul keinginan untuk bunuh diri jika sudah merasa putus asa. Hasil penelitian yang lainnya menunjukkan adanya perasaan tidak berdaya yang sesuai dengan teori yaitu lansia merasa kelelahan atau lemas, tidak mampu dan merasa dirinya tidak berarti. Perasaan bersalah dengan gejala lansia berpikir bahwa orang lain lebih baik dari dirinya yang ditunjukkan pada teori gejala depresi yaitu merasa bersalah terhadap kegagalan yang dialami dan melihat semuanya gagal dan sia-sia. Gangguan pada perhatian/ konsentrasi juga ditunjukkan dari hasil penelitian yaitu lansia sulit dalam berkonsentrasi hal ini sesuai dengan teori yang mengatakan bahwa salah satu gejala dari depresi adalah sulit dalam berkonsentrasi. Gejala lain yang ditunjukkan dari hasil penelitian sesuai dengan parameter GDS adalah kurangnya semangat atau harapan terhadap masa depan, hal ini sesuai dengan yang ditunjukkan dalam teori yaitu gejala depresi lansia adalah memiliki motivasi yang kurang dalam menjalani hidupnya. Faktor psikologis sangat berpengaruh terhadap timbulnya depresi pada lansia. Keinginan lansia adalah tinggal di rumah bersama keluarganya sehingga lansia yang dibawa ke panti atas dasar bukan keinginannya sendiri akan memicu depresi karena lansia akan menemukan tempat yang baru, teman yang baru, kebiasaan yang baru dan adaptasi terhadap kondisi panti. Sehingga lansia yang sulit beradaptasi maka akan menentas dan cenderung menunjukkan perilaku yang maladaptif seperti yang telah dijelaskan sebelumnya.
Mengidentifikasi Depresi Lansia Setelah Dilakukan Senam yoga pada Kelompok Perlakuan dan Kelompok Kontrol di UPT Pelayanan Sosial Lanjut Usia Pasuruan di Lamongan.

Dari hasil penelitian dapat diketahui bahwa dari 14 responden pada kelompok perlakuan sesudah dilakukan senam yoga didapatkan rerata sebesar 16.00dan standart deviasi sebesar 1.568. Sedangkan pada kelompok kontrol data tidak dilakukan senam yoga didapatkan rerata 15.14 dan standart deviasi sebesar 1.610.

Yoga adalah suatu metode untuk menenangkan pikiran yang resah untuk kemudian diarahkan pada saluran yang konstruktif (Widyantoro, 2010). Senam yoga dianjurkan pada penderita stres hingga depresi, karena senam yoga mengkobinasikan antara teknik bernafas, relaksasi, dan meditasi serta latihan peregangan. iki refek relaksasi yang dapat memberikan ketenangangan dalam hati dan dapat mengendalikan emosi, menyatukan badan, pikiran hari dan jiwa (Claire, 2009). Yoga sangat baik untuk meningkatkan konsentrasi dan membawah kesadaran diri, menajamkan pikiran, dan menjauhkan seseorang dari emosi dan pikiran negative. Yoga berperan penting dalam meningkatkan asupan oksigen kedalam otak, menghilangkan kepenatan, meningkatkan energi, dan vitalis, mningkatkan kelenturan dan stamina tubuh, menstimulasi kelenjar hormonal dalam tubuh dan membuatnya stabil. Yoga juga mengstabilkan fungsi kerja tubuh, meningkatkan rasa nyaman, tentram dan beban stres, memperhalus rasa, memperbaiki sikap dan perilaku, meningkat rasa percaya diri, pola fikir yang positif dan penghargaan terhadap diri sendiri, memperlambat proses penuaan diri, 
meningkat daya ingat, focus terhadap satu masalah dan meningkatkan kesehatan secara menyeluruh (holistic), keseimbangan kondisi fisik dan kejiwaan seorang dalam dirinya (Muchtar AF, 2010).

Berdasarkan penelitian senam yoga merupakan salah satu bentuk cara untuk menurunkan depresi pada lansia, karena dengan melakukan senam yoga secara rutin dapat menjadikan otot rileks dan yoga dapat meningkatkan neurotransmitter inhibitory di otak (GABA/ Gama Aminobutic) dan Yoga juga meningkatkan pelepasan endorfin dalam aliran darah sehingga merasa lebih gembira. Gejala umum dari depresi adalah penarikan social. Studi telah menemukan bahwa berlatih yoga dapat meningkatkan hubungan interpersonal. Tidak hanya memberikan ketenangan pikiran, yoga juga akan secara drastic mengubah pendekatan anda terhadap lingkungan sekitar.

\section{Pengaruh Senam Yoga Terhadap Depresi Pada Lansia Di UPT Pelayanan Sosial Lanjut Usia Di Lamongan.}

Berdasarkan hasil uji ststistik dengan uji t test 2 sampel berpasangan menggununakan SPSS for windows 16 menunjukkan bahwa hasil untuk kelompok perlakuan dan kelompok kontrol diketahui bahwa nilai $p$ value $=0,000<\alpha=0,05$, maka Hi Diterima dan Ho ditolak yang berati ada pengaruh senam yoga terhadap depresi pada lansia di UPT Pelayanan Lanjut Usia Pasuruan di Lamongan.

Melakukan senam yoga akan berpengaruh terhadap system limbic di otak yang akan teraktivasi, maka membuat seseorang berespon tehadap emosi dan merangsang cerebal kortex dalam aspek kognitif dan emosi yang positif, sehingga menghasilkan persepsi yang positif yang akan memberikan respon koping menjadi positif dimana dalam al ini akan mempengauhi saraf dan otot menjadi rileks terhadap ketegangan serta depresi akan berkurang dan sirkulasi darah menjadi lancar. Rileks dan stress yang berkurang akan menurunkan aktifitas produksi HPA (Hipotalamik Pituitary Adrenal), yang ditandai dengan adanya peeurunan hormon CRF (Corticotropin Releasing Faktor) di hipotalamus, dan juga merangsang pituitary anterior untuk menurunkan hormon ACTH (Adreno Cortico Tropic Hormon). Penurunan ini juga merangsang medulla adrenal untuk menurunkan produksi hormon katekolamin dan kortisol sebagi horman stres (M. Sholeh, 2006). Dan dengan dilakukan senam yoga dapat meningkatkan neurotransmitter inhibitory di otak (GABA/ Gama - Aminobutic) dan Yoga juga meningkatkan pelepasan endorfin dalam aliran darah sehingga merasa lebih gembira. Senam yoga juga menstimulasi pengeluaran hormon endorfin. Endorphin adalah neuropeptide yang dihasilkan tubuh pada saat relaks/tenang.Endorphin dihasilkan di otak dan susunan syaraf tulang belakang. Hormon ini dapat berfungsi sebagai obat penenang alami yang diproduksi otak yang melahirkan rasa nyaman. Sehingga semakin banyak melakukan senam maka akan semakin tinggi pula kadar $b$ endorphin (Pujiastuti, 2013). Dengan manfaat yoga mengurangi stres dan depresi maka, saat berkonsentrasi, masalah sehari hari, baik besar maupun kecil, akan mencair sehingga akan terbebas dari tekanan stress. Konsentrasi bisa menjadi saranan relaksasi pikiran yang sangat dibutuhkan oleh pikiran yang sedang stress. Tehnik relaksasi yoga jika dikaitkan dengan proses penurunan stress kerja sangat bermanfaat 
untuk memfasilitasi hal tersebut. Menurut Copstead dan Banasik (2000), hipotalamus dapat dimanipulasi agar secara minimal terhadap stressor, dengan cara menghiraukan stressor meskipun dengan konsekuensi tingkat/ level stressor tetap dipertahankan dalam individu. Latihan relaksasi dan konstrasi dalam latihan yoga merupakan sesi latihan yang menggunakan teknik pemusatan pikiran untuk memperkuat sikap positif dalam upaya menurunkan tingkat stress.

Dari hasil penelitian menunjukkan bahwa pada kedua kelompok sama - sama terjadi perubahan penurunan nilai skor depresi, namum perubahan penurunan nilai skor depresi pada kelompok perlakuan lebih besar dari pada kelompok kontrol, hal ini dikareakan pada kelompok kontrol tidak dilakukan senam yoga, sehingga perubahan nilai skor depresi pada kelompok kontrol lebih kecil. Terjadinya perbedaan perubahan nilai skor depresi dikarenakan dengan dilakukannya senam yoga yang sering secara rutin akan berpengaruh besar terhadap penurunan nilai skor depresi.

\section{SIMPULAN}

Terdapat pengaruh senam yoga terhadap depresi pada lansia di UPT Pelayanan Sosial Lanjut Usia Pasuruan di Lamogan $(p$ value $=0,000<\alpha=0,05)$.

\section{SARAN}

Saran dalam penelitian ini adalah tenaga kesehatan dapat mengaplikasikan senam yoga untuk mengurangi tingkat depresi dari lansia agar kualitas hidup lansia tersebut meningkat, terutama bagi lansia yang berada dalam panti werdha atau UPT Pelayanan Sosial Lanjut Usia.

\section{DAFTAR PUSTAKA}

1. Amir, N. 2005. Depresi: Aspek Neurobiologi, Diagnosis, Dan Tata Laksana. Jakarta: Balai Penerbit FKUI.

2. Ansoni, Z.F. 2014 Pengaruh Senam Lanjut Usia Terhadap Penurunan Tingkat Depresi Usia Lanjut Di Posyandu Abadi IV Kartasura. Diakses tanggal 25 Desember 2016

3. Asmarani, D. 2011. Yoga Untuk Semua:Panduan Berlatih Yoga Yang Sehat Dan Aman. Jakarta: PT. Gramedia Pustaka Utama.

4. Azizah, Lilik M. 2011. Keperawatan Lanjut Usia. Yogyakarta: Graha Ilmu.

5. Dewi, I. 2013. Pengaruh Terapi Yoga Pranayama Terhadap Tingkat Depresi Pada Pasien Skizofrenia Di Ruang Nakula Ruma Sakit Jiwa Provinsi Bali. Diakses Pada Tanggal 22 Desember 2015.

6. Fitriani, L. 2011. Pengaruh Senam Lansia Terhadap Tingkat Depresi pada Lansia di Posyandu Lansia Teratai Dusun Ngrenak Kidul 10 Sidomoyo Godean Sleman. Diakses Pada Tanggal 25 Desember 2015.

7. Hawari, D. 2007. Manajemen Stress, Cemas, dan Depresi. Jakarta: FKUI.

8. Hawari, D. 2007. Sejahtera Di Usia Senja: Dimensi Psikoreligi Pada Lanjut Usia (Lansia). Jakarta: Balai Penerbit FKUI.

9. Indonesia Departemen Pendidikan Nasional Pusat Bahasa Indonesia. 2008.Kamus Besar Bahasa Indonesia Pusat Bahasa. Jakarta: Gramedia Pustaka Utama.

10. Kaplan, H.I., Sadock B.J. 1998. Ilmu Kepeawatan Jiwa Darurat. Jakarta: Widya Medika.

11. Kirschner, M.J. 2010. Yoga Untuk Kesehatan Dan Kekuatan. Bandung: Pionir Jaya.

12. Lubis, N. L. 2009. Depresi Tinjauan Psikologis. Jakarta: Kencana.

13. Mariyani. 2014. Pengaruh Terapi Tertawa Terhadap Penurunan Tingkat 
Depresi Lanjut Usia. Diakses 04 Januari 2016.

14. Nugroho, W. 2008. Keperawatan Gerontik \& Geriatrik. Edisi 3. Jakarta: Penerbit Buku Kedokteran EGC.

15. Nursalam, dkk. 2008. Pendidikan Dalam Keperawatan. Jakarta: Salemba Medika.

16. Nursalam. 2013. Konsep Dan Penerapan Metologi Penelitian Ilmu Keperawatan. Edisi 3. Jakarta: Salemba Medika.

17. Sani. 2006. Yoga Untuk Kesehatan. Semarang: Dahara Prize.

18. Shindu, P. 2013. Hidup Sehat Dan Seimbang Dengan Yoga. Bandung: Qanita.

19. Shindu, P. 2004. Handbook of Yoga. Bandung: Qanita.

20. Sugiyono. 2014. Metode Penelitian Pendidikan Pendekatan Kuantitatif, Kualitatif dan R\&D. Bandung: Alfabeta.

21. Ulliya.S, Agustin. D. 2008. Perbedaan Tingkat Depresi Pada Lansia Sebelum Dan Sesudah Dilakukan Senaam Bugar Lansia Dipanti Wredha Wening Wardoyo Ungaran. Diakses 25 Desember 2015.

22. Wahyuni, Sri. 2012. Pengaruh Senam Yoga Terhadap Keseimbangan Pada Lanjut Usia. Diakses Pada Tanggal 04 Januari 2016.

23. Widyantoro, Yudhi. 2010. Yoga Yuk Biar Fit, Fit Pikiran Tubuh dan Jiwa. Jakarta: PT Raketindo Primamedia Mandiri.

Cite This Article As: Murtiyani, N., Lestari, Y.A., Suidah, H., Okhfarisi, H.R. Pengaruh Senam Yoga Terhadap Depresi Pada Lansia Di Upt Pelayanan Sosial Lanjut Usia Pasuruan, Lamongan. Nurse and Health: Jurnal Keperawatan 2018; 7(1): 2330 . 